\title{
Ambient flow velocity and resulting clearance rates of the terebellid polychaete Lanice conchilega (Pallas, 1766)
}

\author{
DENIS Lionel ${ }^{(1)^{*}}$, DESROY Nicolas $^{(1,2)} \&$ ROPERT Michel $^{(3)}$
}

(1) Station Marine de Wimereux, UMR 8013 ELICO - Université des Sciences et Technologies de Lille, 28, Avenue Foch, 62930 WIMEREUX, France

(2) Present adress: Laboratoire Environnement et Ressources - IFREMER, 2 bis Rue Grout de SaintGeorges, 35402 SAINT MALO, France.

(2) Laboratoire Ressources Aquacoles - IFREMER, Avenue du Général de Gaulle, BP 32, 14540 PORT-EN-BESSIN, France.

*Corresponding author; E-mail address: Lionel.Denis@univ-lille1.fr (L. Denis)

\begin{abstract}
:
A laboratory flume study was conducted to determine the effect of flow velocity on clearance rates of the Polychaeta Terebellidea Lanice conchilega (Pallas, 1966). Using sets of 75 individuals collected along the east coast of the English Channel, we measured clearance rates at five flow velocities of $\approx 4$, 9, 15, 22 and $27 \mathrm{~cm} \mathrm{~s}-1$ with a culture of the diatom Chaetoceros calcitrans as food source. During each control (without polychaetes) or clearance (with Lanice conchilega) experiment, in vivo fluorescence was continuously monitored. Further HPLC analysis confirmed the sediment resuspension for the highest flow velocities tested, indicating the need for 'corrections' from control experiments. The global pattern resulted in a dome-shaped curve, with a corrected clearance rate per individual increasing with flow velocity from an average value of $0.091 \pm 0.041 \mathrm{~L} \mathrm{~h}-1 \mathrm{gDW}-1 \mathrm{at} 4 \mathrm{~cm}$ s- 1 up to a maximal value of $0.171 \pm 0.046 \mathrm{~L} \mathrm{~h}-1$ ind -1 at $15 \mathrm{~cm} \mathrm{~s}-1$ and decreasing for higher flow velocity $(0.063 \pm 0.029 \mathrm{~L} \mathrm{~h}-1$ ind -1 at $27 \mathrm{~cm} \mathrm{~s}-1)$. When normalised to average Dry Weight (DW), the clearance rates varied in a wider range, with maximal clearance rates of up to $0.749 \mathrm{~L} h-1$ gDW- 1 and a marked dome-shaped structure for small individuals (11.9 $\pm 5.4 \mathrm{mg}$ Ash Free Dry Weight), whereas larger individuals (up to $30 \mathrm{mg} \mathrm{AFDW)} \mathrm{showed} \mathrm{maximal} \mathrm{clearance} \mathrm{rates} \mathrm{of} \mathrm{around}$ $0.400 \mathrm{~L} \mathrm{~h}-1 \mathrm{gDW}-1$. Our results indicate the need to take flow velocity into account in estimating the ecological impact of filter-feeding polychaetes on available food, as large budget underestimates may arise from clearance rates measured in non-controlled flow velocity.
\end{abstract}

Keywords: Lanice conchilega; Clearance rate; Polychaetes; Terebellidea; Feeding activity; Recirculating flume 


\section{Introduction}

Hydrodynamics has been shown to influence feeding and growth of a large number of benthic organisms in a variety of coastal environments (Kirby-Smith, 1972; Walne, 1972; Wildish and Peer, 1983; Wildish and Kristmanson, 1997, Sobral and Widdows, 2000). The influence has mainly been assessed on active filter feeders (Calahan et al., 1989; Grizzle et al., 1992), studies commonly focusing on the optimal flow characteristics for the growth of cultivated species (Wildish and Miyares, 1990; Wildish and Kristmanson, 1997, Denis et al., 1999). Numerous studies have been conducted on bivalvia, but quantitative information about the filtration and clearance rates in polychaete taxa in response to various current velocities remains rather scarce. The ecological role of polychaetes has been demonstrated in semi-enclosed coastal areas (Davies et al., 1989; Riisgard et al. 2004) where numerous species feed by active or passive clearance of the surrounding water, hence competiting for food with cultivated species. The influence of flow velocity on feeding behaviour was studied on few species: the spionids (Dauer et al., 1981), the sabellids Eudistylia vancouveri (Merz, 1984) and Sabella penicillus (Riisgard and Ivarsson, 1990), and the serpulid Ficopomatus enigmaticus (Davies et al., 1989).

In the bay of Veys, in the western part of the bay of Seine (English Channel, France), the tubicolous polychaete Lanice conchilega proliferates since 1985 (Ropert, 1999) in an area where Pacific oysters Crassostrea gigas (Thunberg, 1795) are widely cultivated. Population dynamics and extension in the bay has been followed and widely described (Ropert and Dauvin, 2000), with maximal densities reaching 7000 ind. $\mathrm{m}^{-2}$ in the oyster production area and raising up the problem of trophic competition for food (Ropert and Goulletquer, 2000). The feeding behaviour of $\underline{L}$. conchilega was previously shown to be deposit or filter feeding, the switch to filtration activity being generally observed for high population densities (Buhr, 1976; Buhr and Winter, 1977). Moreover, according to the classification proposed in Wildish and Kristmanson (1997), the filtration activity should be considered as facultative active suspension feeding, i.e. the filtrationfeeding behaviour changes with velocity so that at low velocities active filtration occurs, while above a critical higher velocity passive suspension feeding is observed. For Lanice conchilega, filter feeding activity may be active, by randomly moving tentacles through the water at low flow velocities, or passive at higher flow velocities, still tentacles being supported by the sandy fringe of the tube. From experiments carried out in still water conditions, Ropert and Goulletquer (2000) concluded that feeding competition is likely to occur between the both species as $\underline{L}$. conchilega may

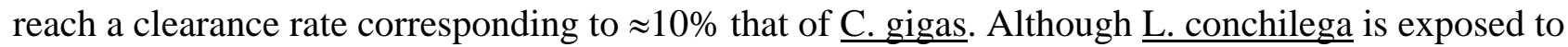
both wide variations in water currents and suspended particulate matter, previously no study focused on the feeding response of this polychaete to changing current velocities. In the bay of

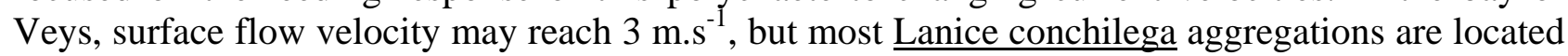
under the oyster cultivation beds, where the farming structures modify the hydrodynamic pattern and considerably reduce water motion. The aim of the present work is to quantify the clearance activity of L. conchilega with increasing flow velocity, and to subsequently assess the role of this gregarious species as a competitor for farmed bivalves, taking into account the hydrodynamic environment.

\section{Material and Methods}

\subsection{Material sampling and processing}

Individuals were sampled from two intertidal populations located in the bay of Veys (Western bay of Seine) on June 2000, and along Boulogne-sur-Mer harbour (Eastern English Channel) on July 2000 (Table I). The animals were collected with a hand corer (area sampled: 0.02 $\mathrm{m}^{2}$, depth: $30 \mathrm{~cm}$ ), gently washed with seawater through a 1-mm sieve and put into isothermal boxes containing a layer of sand and seawater. After transport to the laboratory, polychaetes were transferred to enclosures filled with 1-mm sieved natural fine sand sampled in the same area as the worms (250-300 $\mu \mathrm{m}$ median particle size) and kept in running seawater aquaria $\left(16-19^{\circ} \mathrm{C}\right)$ until their transfer in pipet tips (see below). Few days later, most polychaetes had embedded themselves 
in the sediments or developed a new tube as reported by Buhr (1976). The remaining bulk sediments were passed through a 1-mm sieve to remove macrofauna and coarse particles, exposed to air for one week, and used to fill the enclosures for clearance and control experiments.

\subsection{Phytoplanktonic cells}

The diatom Chaetoceros calcitrans (Bacillariophyceae) was chosen as diet for $\underline{L}$. conchilega. This species, common in shallow waters, was previously used for filtration experiments (Mc Causland et al., 1999; Devakie and Ali, 2000). Cells with sizes ranging from 3 to $6 \mu \mathrm{m}$ in diameter, can easily be collected by L. conchilega which retain particles mainly ranging from 4 to up to 12 $\mu \mathrm{m}$ (Ropert and Goulletquer, 2000). Algae were grown at the laboratory in $\mathrm{f} / 2$ medium at $18^{\circ} \mathrm{C}$ (Guillard and Ryther, 1962) under 12/12 dark-light conditions.

\subsection{Experimental device}

Experiments were conducted in an racetrack, recirculating laboratory flume (developed length $=3.9 \mathrm{~m}$ length, $0.4 \mathrm{~m}$ height, $0.4 \mathrm{~m}$ width, Figure 1 ) equipped with a variable speed electric motor coupled to rotating vertical PVC disks immersed in the water and creating a current up to 50 $\mathrm{cm}^{-1}{ }^{-1}$. The experimental section, located at the centre of the straight line (length $=1 \mathrm{~m}$ ) is constituted with a removable PVC tank (0.7 m length, $0.3 \mathrm{~m}$ width, $0.3 \mathrm{~m}$ depth). Free-stream velocity was measured over the test section using hot-film sensor. Five minutes were necessary to obtain flow stabilization after each velocity increment and measurements were then performed during 1 minute at the beginning and the end of each velocity tested.. Although a longer flume as used by Desroy and Retière (2000) is desirable for maintaining a well-developed and predictable boundary layer (Nowell and Jumars, 1987), the choice of a small flume was imposed by the volume of algal culture reasonably obtainable at the laboratory for experiments. Direct measurements of in vivo fluorescence were performed by means of a Sea Tech fluorometer fixed into the flume and connected to a Sea-Bird 25 CTD probe, which allowed direct data monitoring by a computer. All experiments were conducted under continuous light conditions, at a temperature of $18^{\circ} \mathrm{C}$ of and salinity of 30 .

\subsection{Experimental protocol and clearance rate calculations}

Two treatments were tested: (i) without polychaetes, to estimate the suspended particulate matter and to account for any change in phytoplankton concentration that could not be attributed to polychaetes (control) and (ii) with 75 individuals of $\underline{\mathrm{L}}$. conchilega in the experimental section, to measure their clearance rate under varied flow conditions (this treatment was replicated three times).

For the control experiment, a removable PVC enclosure adaptable to the experimental section of the flume was filled with sieved fine sand and kept in running water.

For experiments with polychaetes, linear parts of 3x75 sandy tubes (with the animal inside) were cut to a length of approximately 3-4 $\mathrm{cm}$ to avoid abnormal tube geometry. All tubes containing the worms were introduced individually in $3 \times 75$ plastic pipet tips $(20 \mathrm{ml})$ filled with sieved natural sediment sampled in the same area as the worms. Each set of 75 pipet tips with $\underline{\text { L. conchilega was }}$ put into the experimental section of the flume, which was previously filled with defaunated fine sand, and kept in running water one week until the clearance experiment. The use of pipet tips allowed an easy and homogeneous distribution of the individuals $(5 \mathrm{~cm}$ between neighbouring organisms) and adjustment of the sandy fringe above the sediment-water interface. L. conchilega individuals became active within a few hours, as indicated by the appearance of their tentacles out of their tubes, and reconstituted their tube with a wide sandy fringe in 2-3 days.

For each experiment, one enclosure (with or without worms) was placed in the experimental section of the flume, which was filled with filtered seawater $(1 \mu \mathrm{m})$ to a depth of $10 \mathrm{~cm}$. Algal cultures were added up to a concentration around 25-30 $\mu \mathrm{g}$ Chl a. $\mathrm{l}^{-1}$ and homogenized at $4 \mathrm{~cm} . \mathrm{s}^{-1}$ freestream velocity during 2-3 min (checked with continuous fluorescence recordings). Finally, water 
level was adjusted in the flume to obtain a total volume of $100 \mathrm{l}$. Control and clearance experiments were begun after 30 minutes. Different free-stream velocities were successively tested during $1 \mathrm{~h} 45$ each: 4, 9, 15, 22 and $27 \mathrm{~cm} . \mathrm{s}^{-1}$ and gradient measurements demonstrated that the phytoplankton cells were well-mixed in the flume. Clearance rate calculations in still water conditions were abandoned because Chla depletion in the direct vicinity of L. conchilega tubes may have resulted in severe Chla gradients in the flume and consequent bias in the calculation of clearance activity. For each velocity, in vivo fluorescence was recorded every $15 \mathrm{~min}$. during $1 \mathrm{~min}$., and three water samples $(500 \mathrm{ml})$ were jointly pumped at mid-depth, at the beginning and at the end of each velocity tested. They were filtered on GF/C Whatman glass fiber filters, and deep-frozen $\left(-18^{\circ} \mathrm{C}\right)$ directly in the glass tube where extraction for HPLC analysis was performed. Before each velocity increase,

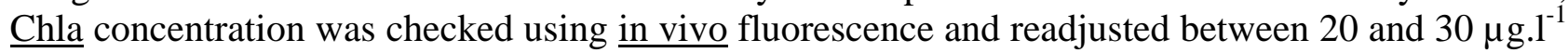
through adding a calculated volume of algal culture. At the end of the clearance experiment, all individuals were collected, checked for dead organisms, and living ones were fixed in $5 \%$ formalin before wet flesh weight, dry flesh weight $\left(72 \mathrm{~h}-65^{\circ} \mathrm{C}\right)$ and Ash-free dry flesh weight determination $\left(6 \mathrm{~h}-520^{\circ} \mathrm{C}\right)$.

Clearance rates were calculated from incremental decreases in Chlorophyll as represented by the curve $e^{-x}$, where $-x$ is the slope, whereas $x$ is the specific loss rate due to the clearance activity of Lanice conchilega (Cole et al., 1992). For each flow velocity, the specific loss rate is given by the slope of a linear regression of $\ln$ (estimated $\mathrm{Chl}$ a) against time $\left(\mathrm{h}^{-1}\right)$. Hence, the individual clearance rate (in $1 . h^{-1}$.ind ${ }^{-1}$ ) was calculated with the following formula:

$$
\text { Clearance rate }=\left(x-x^{\prime}\right) \times\left(\frac{V}{N}\right),
$$

where $\mathrm{x}^{\prime}$ is the specific loss rate $\left(\mathrm{h}^{-1}\right)$ during the control experiment, $\mathrm{V}$ is the total volume of water in the flume (100 l), and $\mathrm{N}$ is the number of polychates experimented (Denis et al., 1999).

Clearance rate was calculated per individual, but were also normalized per gram of dry flesh weight (DW) to account for differences in mean size. Values standardized to an individual of $1 \mathrm{~g}$ dry meat weight were calculated, using the formula $F_{s}=\left(1 / W_{e}\right)^{b} \times F_{e}$ developed by Bayne and Newell (1983) with $\mathrm{F}_{\mathrm{s}}$ : Clearance rate normalized to an animal of $1 \mathrm{~g}$ dry flesh weight, $\mathrm{W}_{\mathrm{e}}$ : Measured average dry meat weight of the animals experimented (g), b: allometric coefficient $=0.3159$ according to Buhr (1976), and $\mathrm{F}_{\mathrm{e}}$ : individual clearance rate.

\subsection{HPLC analysis}

Frozen filters were ground in $90 \%$ acetone and placed for $2 \mathrm{~h}$ at $4^{\circ} \mathrm{C}$. The HPLC system was a Beckman Gold System, equipped with a reverse phase C18 column. The detection of pigments was both spectrophotometric (440nm, Beckman Gold System model 167) and fluorometric (excitation: 407nm, emission 420-700nm, Kontron SFM 25), following Brunet et al. (1996). HPLC

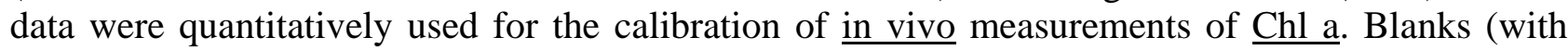
only GF/C filter) were systematically analyzed.

\section{Results}

\subsection{Experimental polychaetes}

Among the 75 individuals of $\underline{L}$. conchilega used in each experiment, six were dead at the end of the clearance experiments 1 and 2 and a single dead organism was found in experiment 3 (Table I). Considering their decomposition state observed during tube retrieval, we assumed that those organisms died before the beginning of the clearance experiment and they were not considered for clearance rates calculations.

The average dry weights of polychaetes used in each experiment were significantly different (oneway ANOVA, $\mathrm{p}<0.001$ ), and the individuals sampled near Boulogne-sur-Mer showed a twicehigher dry weight than those collected in the bay of Veys (Table I). 


\subsection{Effect of current velocity on particles resuspension}

Some resuspension of faeces and rolling of sand grains was observed from free stream velocities around $14 \mathrm{~cm} . \mathrm{s}^{-1}$. For greater current velocities, small sand ripple marks appeared and at a free stream velocity of $27 \mathrm{~cm} . \mathrm{s}^{-1}$ sediment resuspension was continuous and a slow downstream migration of sand ripples was observed. The qualitative analysis of the suspended pigments using HPLC (Figure 2) confirmed that algal culture was mainly characterized by few pigments: Chlorophyll $\mathrm{c}_{1}+\mathrm{c}_{2}$, Fucoxanthin, Diadinoxanthin, Cis-Fucoxanthin and Chlorophyll a (respectively peaks $n^{\circ} 1,2,34$, and 5 - Figure 2c). A similar pigment signature was observed in the flume during all control and clearance experiments (Figure 2a) except at flow velocity of $27 \mathrm{~cm} . \mathrm{s}^{-1}$ characterized by numerous accessory peaks (Figure 2b). Most of the pigments that appeared at this stage were also found in HPLC analysis of the sediments used in the enclosure (Figure 2d) and could be attributed to sediment resuspension.

\subsection{Effect of current velocity on clearance rate}

Figure 3 shows typical changes of $\mathrm{Chl}$ a concentration in the water column at different freestream velocities, with the readjustment in cell concentration before the change of flow velocity in the presence of $\underline{L}$. conchilega.

In control experiment without $\underline{L}$. conchilega, curve slopes were low but increased with flow

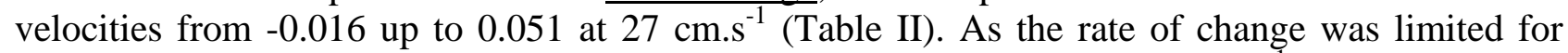
lower flow velocity tested, linear adjustments were rather poor $\left(8.97 \mathrm{~cm} . \mathrm{s}^{-1}: \mathrm{p}<0.05\right)$ or not significant (4.21 and $14.99 \mathrm{~cm} . \mathrm{s}^{-1}$ ). For higher flow velocities, highly significant relationships $(\mathrm{p}<0.001)$ were found and revealed an increase of in vivo fluorescence.

In contrast with the results obtained during control experiments, highly significant decreases of pigment concentration $(\mathrm{p}<0.001)$ were always observed during experiments in the presence of $\underline{L}$. conchilega, except for the velocity of $27 \mathrm{~cm} . \mathrm{s}^{-1}$. A maximum value was found around 9 or $14 \mathrm{~cm} . \mathrm{s}^{-}$ , and a decreased for higher flow velocities. Uncorrected clearance rates showed a similar pattern, but the results obtained after correction from control experiment demonstrated the role of sedimentation, adsorption of algal cells, or resuspension events.

The correction of individual clearance rates from control experiments gives a general domeshaped curve (Figure 4a). For both experiments, a maximum clearance rate was observed either at $14 \mathrm{~cm} . \mathrm{s}^{-1}$ (Exp. 1 and 2) or at $9 \mathrm{~cm}^{-1}$ (Exp. 3). When averaging the experimental values, the maximum clearance rate $\left(0.171 \pm 0.045 \mathrm{l} . \mathrm{h}^{-1}\right.$.ind $\left.{ }^{-1}\right)$ occurs at a current velocity of $14 \mathrm{~cm} . \mathrm{s}^{-1}$ and declines with increasing velocities, particularly above $22 \mathrm{~cm} . \mathrm{s}^{-1}$. At velocities around $27 \mathrm{~cm} . \mathrm{s}^{-1}$, the clearance rate $\left(0.063 \pm 0.0291 . \mathrm{h}^{-1} . \mathrm{ind}^{-1}\right)$ is reduced by more than $50 \%$. The general dome-shaped curve is particularly marked in Exp. 1 with maximal clearance rate reaching $0.221 \mathrm{l}^{-1} \mathrm{~h}^{-1}$. $\mathrm{ind}^{-1}$, whereas the pattern observed for lower flow velocities (4 to $14 \mathrm{~cm} . \mathrm{s}^{-1}$ ) is less clear in Exp. 2 and 3. The normalized clearance rates expressed per gram of dry flesh weight show a similar pattern (Figure 4b). Average clearance rate observed for individuals collected in the bay of Veys represents $0.4571 . \mathrm{h}^{-1}$. gDW ${ }^{-1}$ with a maximal value of $0.749 \mathrm{l} . \mathrm{h}^{-1} . \mathrm{gDW}^{-1}$ whereas the average values observed for the individuals from Boulogne sur Mer (Exp. 2 and 3) were respectively of 0.330 and $0.2701 . h^{-}$ ${ }^{1} \cdot \mathrm{gDW}^{-1}$.

\section{Discussion}

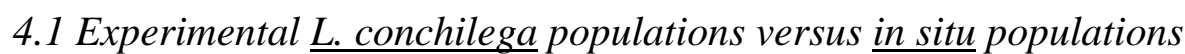

The sets of experimental polychaetes had average individual dry flesh weights ranging between 21.0 and $59.9 \mathrm{mg}$. Globally, individuals tested approximately corresponded to the two major size class identified in the bay of Veys (Ropert, 1999; Ropert and Dauvin, 2000).

Abundances of $\mathrm{L}$. conchilega tested $\left(\approx 360\right.$ ind. $\left.\mathrm{m}^{-2}\right)$ were lower than maximum value reported for the oyster culture area in the bay of Veys, where they reach up to 3300 ind.m ${ }^{-2}$ (Ropert and Dauvin, 2000). Such a density may not be restored experimentally without considering the potential local depletion in algal concentration for individuals located downstream in the test 
section (Riisgard et al., 1996). Buhr (1976) demonstrated that L. conchilega can switch from a filter-feeding mode (Buhr and Winter, 1977) to a deposit-feeding mode when density decreases (Ziegelmeier, 1969), but in our experiments, despite low densities, no individual was observed

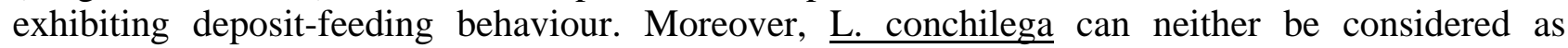
completely passive feeders, individuals feeding in still water by moving their tentacles in the water, nor as completely active feeders, their still tentacles being supported by the sandy fringe of the tube when a higher current velocity is applied. A switch from active to passive feeding behaviour was observed during the experiments between 4 and $8 \mathrm{~cm} \cdot \mathrm{s}^{-1}$.

\subsection{Experimental settings: evidence of algal settling and resuspension}

The coupled analysis, using both in vivo fluorescence and HPLC, revealed the complex interactions that occured in the flume. In the control experiment, a significant decrease of Chl a concentration was observed at $9 \mathrm{~cm} . \mathrm{s}^{-1}$, whereas a significant increase was observed at 22 and 27 $\mathrm{cm} . \mathrm{s}^{-1}$. For low velocities, the decay may be the consequence of diatom settling on the bottom (that may be due to the stress imposed on the algal culture by the change between culture and experimental conditions) or of adsorption on the flume sidewalls as already reported by Denis et al. (1999). This phenomenon recorded at 4 and $9 \mathrm{~cm} . \mathrm{s}^{-1}$, was progressively balanced (at $15 \mathrm{~cm} . \mathrm{s}^{-1}$ ) and replaced (at 22-27 cm.s ${ }^{-1}$ ) by resuspension from the sidewalls and the bottom of the flume. For high velocities, the increase of in vivo fluorescence may result from the resuspension of (i) cultured phytoplankton cells that had previously settled on the bottom or were adsorbed on the sidewalls of the flume or (ii) microphytobenthos present in the surficial sediments of the test section. HPLC analysis revealed that, for low or moderate current (up to $22 \mathrm{~cm} . \mathrm{s}^{-1}$ ), pigments clearly characterized the algal culture of $\underline{C}$. calcitrans, whereas for the highest flow velocity tested $\left(27 \mathrm{~cm} . \mathrm{s}^{-1}\right)$, numerous additional peaks appeared, indicating microphytobenthos resuspension (Figure 2). Similar patterns were observed during the clearance experiments despite the presence of numerous pipet tips and $\underline{L}$. conchilega tubes in the enclosure that may modify the near-bed hydrodynamics and destabilize surficial sediments (Luckenbach, 1986; Jones et al., 1994; Friedrichs et al., 1999). Shear stress around polychates tubes may have been widely modified when free-stream flow velocity was changed, but measurements at a relevant scale are very difficult to carry out and remain very poorly documented.

\subsection{Clearance rates}

For all experiments, individual clearance rates ranged between 0.030 and $0.2211 . \mathrm{h}^{-1}$. Insignificant slopes observed at $27 \mathrm{~cm} . \mathrm{s}^{-1}$ during experiments 2 and 3 may be due to the counterbalance between the decrease linked to clearance activity and the resuspension, resulting in very low changes with time of pigment concentration in the water column. The dome shaped curve obtained for clearance rates versus flow velocity is in poor agreement with the results reported by Buhr (1976). Despite maximal clearance rate (around $0.088 \mathrm{l} \cdot \mathrm{h}^{-1} . \mathrm{ind}^{-1}$ ) close to our observations, Buhr (1976) reports values ranging between 0.009 and $0.026 \mathrm{l}^{-1} \mathrm{~h}^{-1}$.ind $\mathrm{f}^{-1}$ for a flow velocity of 15 $\mathrm{cm} . \mathrm{s}^{-1}$ and for a number of $\mathrm{L}$. conchilega ranging from 76 to 174 . Nevertheless, (i) the duration of the experiment was longer (21-40 days) and we can wonder whether the hydrodynamic forcing applied on those organisms in the experimental setting may be compared with the linear flow velocity that was obtained in the recirculating flume for short periods and, (ii) the high density of $\underline{L}$. conchilega used by this author may reduce food availability for each individual. This effect can be enhanced when a skimming flow is created, because in such a flow regime, the maximum turbulence occurs away from the sediment bed. According to Nowell and Church (1979), skimming flow occurs when more than $8 \%$ of the surface is covered with tubes. In our experiments, supposing an average tube diameter of $3 \mathrm{~mm}$, skimming flow can be expected at densities exceeding 1000 individuals of Lanice conchilega in the test section whereas the maximum density was only 75 individuals. Then, skimming flow was probably not likely to occur in our experiments. During the experiments conducted by Buhr (1976), the density was one individual per $\mathrm{cm}^{2}$ against one per 14 
$\mathrm{cm}^{2}$ in our experiments and skimming flow may have occurred, hence increasing the probability of food depletion close to the animals.

From single individual submitted to a minimal hydrodynamic forcing, not measured but presumed to be in the range $0-5 \mathrm{~cm} . \mathrm{s}^{-1}$, Ropert and Goulletquer (2000) obtained clearance rates of 0.074 and $0.1091 . h^{-1}$.ind ${ }^{-1}$ but calculations were performed only on individuals indicating an active filtration during their experiment Those data are very similar to our measurements at $4 \mathrm{~cm}_{\mathrm{s}} \mathrm{s}^{-1}$, whereas in our design, a set of 75 organisms was chosen for each experiment to take into account a part of the inter-individual variability, as well as the potential rhythm of filtration activity previously shown for other species (Duchêne et al., 2000). For most of the individuals, the presence and length of tentacles out of the tubes varied widely with time. Even if no clear relationship has ever been observed between the number of tentacles emerging from the tube and the individual clearance rate, we might expect that the temporary absence of tentacles out of the tube indicates a low nutritional activity (Jordana et al., 2000).

According to Pilditch and Grant (1999), previous feeding history is a critical factor affecting the feeding response of bivalvia (giant scallops) and internal energy demands alter the threshold speed at which feeding inhibition occurs (i.e. for starved organisms, the inhibition velocity is elevated). Such a phenomenon, also pointed out in the serpulid polychaete Ditrupa arietina (Jordana et al., 2000), may introduce a bias in the direct comparison between our treatments, which organisms were sampled in two different locations (with potentially different food stocks).

Even if L.conchilega should be considered as passive suspension-clearers for the range of velocities tested, comparison with clearance rates of active suspension-feeders may be done in the context of a potential competition for food. The general dome-shaped curve obtained between clearance rate and flow is consistent with studies performed with active filter-feeders (Denis et al., 1999; Pilditch and Grant, 1999; Sobral and Widdows, 2000), or the general theoretical ecosystem response to water movement perturbation for a passive feeder (Wildish and Kristmanson, 1997). Studies conducted with bivalve filter-feeders often show a decline of growth, clearance and feeding rates, while flow velocity was decreased (Grizzle et al., 1992; Lenihan et al., 1996). In this range, the hydrodynamic forcing applied on organisms allows clearance processes to proceed up to an optimum rate, whereas for higher flow velocities, water motion becomes a stress source, affecting the efficiency of the filtration system and the energy yield (Wildish and Kristmanson, 1997). Those effects are generally attributed to the passive enhancement of the organism's ability to move water through the mantle cavity and thereby improve the efficiency of the ciliary pump (Wildish and Kristmanson, 1993; Lenihan et al., 1996). A similar effect may be hypothesized for L. conchilega while considering that the fringed ends of the tube may act as a trap rather than a sieve (Carey, 1983), hence with efficiency directly correlated with (flow velocity $\times$ particle concentration) for moderate flow. But bivalvia have the ability to control valve opening, hereby controlling hydrodynamic pressure on the gills for higher flow velocities, whereas polychaetes have to face a higher disturbance level. Moreover, once retained by the mucus on tentacles, particles are directed towards the mouth by ciliary motions (Fauchald and Jumars, 1979), which may be affected by high flow velocities, as recently described for bivalvia (Ward et al., 2003). Inhibition of clearance activity in $\underline{L}$. conchilega may also be partly due to the resuspension of inorganic particles, accumulating on the tentacles, and leading to a poor energy yield feeding activity.

The dome-shaped pattern is very marked in Exp. 1, with small sized organisms (mean DW: $21 \mathrm{mg}$ ), up to a maximal clearance rate of $0.749 \mathrm{l} . \mathrm{h}^{-1} \cdot \mathrm{gDW}^{-1}$ at $15 \mathrm{~cm} \cdot \mathrm{s}^{-1}$, i.e. almost 8 times higher than at $27 \mathrm{~cm} . \mathrm{s}^{-1}$. On the contrary, larger sized animals show less variation, always in the range 0.119-0.419 $1 . \mathrm{h}^{-1} \cdot \mathrm{gDW}^{-1}$. Moreover, clearance rates normalized per gram of dry flesh weight ranged from 0.1 to $0.75 \mathrm{l} . \mathrm{h}^{-1} . \mathrm{gDW}^{-1}$, which is in the same order of magnitude as the values obtained for other suspension feeding polychaetes (as summarized in Riisgard and Ivarsson, 1990).

Further direct comparison between species is difficult as the filtration rate per individual leads to major differences due to the weight of the organisms, and the comparison of values 
normalized for $1 \mathrm{~g}$ dry flesh weight needs knowledge of the b exponent for each species (Riisgard and Larsen, 2000). In Lanice conchilega, the size range commonly tested does not allow an accurate estimation of allometric coefficients, and we used the b exponent of 0.3159 reported by Buhr (1976) and Ropert and Goulletquer (2000), close to the value of 0.24 used by Riisgard and Ivarsson (1990) for Sabella penicillus. But one may consider a margin of error on normalized data, as the $b$ exponent is rather poorly documented for polychaetes.

For global budget calculations in the Bay of Veys, we considered approximately constant ratio (20\% / 80\%) between juveniles (Tube diameter $<2.8 \mathrm{~mm}$, Exp1) and adults (Tube diameter $>2.8 \mathrm{~mm}$, Exp3) of Lanice conchilega, and average densities around 3500 ind. $\mathrm{m}^{-2}$ (Ropert, 1999). Assuming that polychaetes densities observed in situ (2 to 7 times higher than in flume studies) do not interfere with the clearance rates, i.e. no food depletion happens close to the Lanice conchilega, further calculations may be performed. Then, based on the wider range of individual clearance rates observed (assuming a maximum at $15 \mathrm{~cm} \cdot \mathrm{s}^{-1}$ and a minimum at $4 \mathrm{~cm} \cdot \mathrm{s}^{-1}$ ) the mean clearance rate of polychaetes may be estimated between 158 and $5781 . \mathrm{h}^{-1} \cdot \mathrm{m}^{-2}$ in the oyster cultivation area (Table III). These estimates are lower than the average value presented for Crassostrea gigas in the same area, i.e. $677.131 . \mathrm{h}^{-1} \cdot \mathrm{m}^{-2}$ (Ropert and Goulletquer, 2000), but are of the same order of magnitude. Despite a more passive filtration activity, hence more dependent on current velocity, the retention efficiency of $\underline{L}$. conchilega as well as very high densities, lead to this potential competition for food between polychaetes and oysters. For Lanice conchilega beds, the calculation of global clearance rate based on individual clearance rates obtained at lower densities may erroneous, overestimating the global clearance due to polychaetes. But similar density effect leading to food depletion may also affect oyster beds, significantly decreasing their filtration activity, hereby not calling the possible competition between polychaetes and mollusks into question. The potential competition for food is all the more important as highest densities of polychaetes are generally observed in the direct vicinity of oysters beds rather than in channels separating cultivation beds, and may therefore lead to local depletion of algae in the water column close to the oysters. Moreover, Ropert and Goulletquer (2000) demonstrated that the retention spectra of $\underline{L}$. conchilega and $\underline{\text {. gigas may easily }}$ interfere for particles in the range 2-13 $\mu \mathrm{m}$.

As the effect of flow velocity on clearance rates may also depend on particle concentrations, mainly for passive suspension-clearers Grizzle and Lutz (1989) and Emerson (1990) suggested that food flux (e.g. velocity x particles concentration) is a better predictor of growth rather than the separate parameters. In our study, only the influence of flow velocity was explored, and complementary experiments are still needed for a better understanding of Lanice conchilega clearance activity, such as the quantity and quality of food, the balance between inorganic and organic particles in the water column, and the small-scale turbulence patterns created by the sandy fringes of the tube, as well as tube aggregations. But our results clearly demonstrate the necessity to integrate the effect of current velocity on clearance activity for estimating the impact of $\underline{L}$. conchilega in coastal ecosystems.

\section{Acknowledgements}

The authors are grateful to Marie-André Janquin for HPLC analysis, Stéphane Gasparini for providing algal cultures, Yves Lemoine for Chromatogram analysis, and Thomas Tourbier for his help during sampling and preliminary experiments with polychaetes. Moreover, the author would like to thank Jean-Claude Dauvin for his valuable comments, as well as anonymous reviewers who amply contributed to the improvement of this manuscript.

\section{References}

Bayne, B.L., Newell, R.C., 1983. Physiological energetics of marine mollusks. In: Wilbur, K.M., Saleuddin, S.M. (Eds), The Mollusca, 4(1). Academic Press, London, pp. 407-515. 
Brunet, C., Brylinski, J.M., Bodineau, L., Thoumelin, G., Bentley, D., Hilde, D., 1996. Phytoplankton dynamics during the spring bloom in the south-eastern English Channel. Est. Coast. Shelf Sci. 43, 469-483.

Buhr, K.J., 1976. Suspension-feeding and assimilation efficiency in Lanice conchilega (Polychaeta). Mar. Biol. 38, 373-383.

Buhr, K.J., Winter, J.E., 1977. Distribution and maintenance of a Lanice conchilega association in the Weser estuary (FRG), with special reference to the suspension-feeding behaviour of Lanice conchilega. In: Keegan, B.F., Ceidigh, P.O., Boaden, P.J.S. (Eds), Biology of Benthic Organisms: 11th European Symposium on Marine Biology, Galway, October 1976. Pergamon Press, Oxford, pp. 101-113.

Cahalan, J.E., Siddall, S.E., Luckenbach, M.W., 1989. Effects of flow velocity, food concentration and particle flux on growth rates of juvenile bay scallops Argopecten irradians. J. Exp. Mar. Biol. Ecol. 129, 45-60.

Carey, D.A., 1983. Particle resuspension in the benthic boundary layer induced by flow around polychaete tubes. Can. J. Fish. Aquat. Sci. 40, 301-308.

Cole, B.E., Thompson, J.K., Cloern, J.E., 1992. Measurement of filtration rates by infaunal bivalves in a recirculating flume. Mar. Biol. 113, 219-225.

Dauer, D.M., Maybury, C.A., Ewing, R.M., 1981. Feeding behavior and general ecology of several spionid polychaetes from Chesapeake Bay. J. Exp. Mar. Biol. Ecol. 54, 21-38.

Davies, B.R., Stuart, V., De Villiers, M., 1989. The filtration activity of a serpuli polychaete population (Ficopomatus enigmaticus Fauvel) and its effects on water quality in a coastal marina. Est. Coast. Shelf Sci. 29, 613-620.

Denis, L., Alliot, E., Grzebyk, D., 1999. Clearance rate responses of Mediterranean mussels, Mytilus galloprovincialis, to variations in the flow, water temperature, food quality and quantity. Aquat. Liv. Res. 12, 279-288.

Desroy, N., Retière, C., 2000. Effet de l'hydrodynamisme sur la relation proie-prédateur. Approche expérimentale en canal hydrodynamique. C. R. Acad. Sci. Paris, Sciences de la vie/ Life Sciences 323, 565-572.

Devakie, M.N., Ali, A.B., 2000. Effects of storage temperature and duration on the setting and postset spat survival of the tropical oyster, Crassostrea iredalei (Faustino). Aquaculture 190, 369-376.

Duchêne, J.-C., Jordana, E., Charles, F., Grémare, A., Amouroux, J.-M., 2000. Experimental study of filtration activity in Ditrupa arietina (Annelida Polychaeta) using an automated image analysis system. Oceanologica Acta 23, 805-817.

Emerson, C.W., 1990. Influence of sediment disturbance and water flow on the growth of the soft shell clam, Mya arenaria L.. Mar. Ecol. Prog. Ser. 108, 119-132.

Fauchald, K., Jumars, P.A., 1979. The diet of worms: a study of polychaete feeding guilds. Oceanogr. Mar. Biol. Ann. Rev. 17, 193-284. 
Friedrichs, M., Graf, G., Springer, B., 1999. Skimming flow induced over a simulated polychaete tube lawn at low population densities. Mar. Ecol. Prog. Ser. 192, 219-228.

Grizzle, R.E., Langan, R., Huntting Howell, W., 1992. Growth responses of suspension-feeding bivalve molluscs to changes in water flow: differences between siphonate and nonsiphonate taxa. J. Exp. Mar. Biol. Ecol. 162, 213-228.

Grizzle, R.E., Lutz, R.A., 1989. A statistical model relating horizontal seston fluxes and bottom sediments characteristics to the growth of Mercenaria mercenaria. Mar. Biol.102, 95-105.

Guillard, R.R.L., Ryther, J.H., 1962. Studies on marine planktonic diatoms:I. Cyclotella nana (Hustedt) and Detonula confervaceae (Cleve). Can. J. Microbiol. 8, 229-239.

Jones, C.G., Lawton, J.H., Shachak, M., 1994. Organisms as ecosystem engineers. Oikos 69, 373386.

Jordana, E., Duchêne, J.-C., Charles, F., Grémare, A., Amouroux, J.-M., 2000. Experimental study of suspension-feeding activity in the serpulid polychaete Ditrupa arietina (O.F. Müller). J. Exp. Mar. Biol. Ecol. 252, 57-74.

Kirby-Smith, W.W., 1972. Growth of the bay scallop: the influence of experimental water currents. J. Exp. Mar. Biol. Ecol. 8, 7-18.

Lenihan, H.S., Peterson, C.H., Allen, J.M., 1996. Does flow speed also have a direct effect on growth of active suspension-feeders: An experimental test. Limnol. Oceanogr. 41, 1359-1366.

Luckenbach, M.W., 1986. Sediment stability around animal tubes: the roles of hydrodynamic processes and biotic activity. Limnol. Oceanogr. 31, 779-787.

McCausland, M.A., Brown, M.R., Barrett, S.M., Diemar, J.A., Heasman, M.P., 1999. Evaluation of live microalgae and microalgal pastes as supplementary food for juvenile Pacific oysters (Crassostrea gigas). Aquaculture 174, 323-342.

Merz, R.A., 1984. Self-generated versus environmentally produced feeding currents: a comparison for the sabellid polychaete Eudistylia vancouveri. Biol. Bull. 167, 200-209.

Nowell, A.R., Church M., 1979. Turbulent flow in a depth limited boundary layer. J Geophys. Res. $84,4816-4824$

Nowell, A.R., Jumars, P.A., 1987. Flumes: theoretical and experimental considerations for simulations of benthic environments. Oceanogr. Mar. Biol. Ann. Rev. 25, 91-112.

Pilditch, C.A., Grant, J., 1999. Effect of variations in flow velocity and phytoplankton concentration on sea scallop (Placopecten magellanicus) grazing rates. J. Exp. Mar. Biol. Ecol. 240, 111-136.

Riisgard, H.U., Ivarsson, N.M., 1990. The crown-filament pump of the suspension-feeding polychaete Sabella penicillus: filtration, effects of temperature, and energy cost. Mar. Ecol. Prog. Ser. 62, 249-257.

Riisgard H.U., Larsen P.S., 2000. Comparative ecophysiology of active zoobenthic filter feeding, essence of current knowledge. J. Sea Res. 44, 169-193. 
Riisgard, H.U., Poulsen, L., Larsen, P.S., 1996. Phytoplankton reduction in near-bottom water caused by filter-feeding Nereis diversicolor: Implications for worm growth and population grazing impact. Mar. Ecol. Prog. Ser. 141, 47-54.

Riisgard, H.U., Seerup, D.F., Jensen, M.H., Glob, E., Larsen, P.S., 2004. Grazing impact of filterfeeeding zoobenthos in a Danish flord. J. Exp. Mar Biol. Ecol. 307, 261-271.

Ropert, M., 1999. Caractérisation et déterminisme du développement d'une population de l'Annélide tubicole Lanice conchilega (Pallas, 1766) (Polychète Térébellidé) associé à la conchyliculture en Baie des Veys (Baie de Seine Occidentale). PhD Thesis, Muséum National d'Histoire Naturelle, Paris, France.

Ropert, M., Dauvin, J.-C., 2000. Renewal and accumulation of a Lanice conchilega (Pallas) population in the Baie des Veys, western bay of Seine. Oceanol. Acta 23, 529-546.

Ropert, M., Goulletquer, P., 2000. Comparative physiological energetics of two suspension feeders: polychaeta annelid Lanice conchilega (Pallas 1966) and Pacific cupped oyster Crassostrea gigas (Thunberg 1795). Aquaculture 181, 171-189.

Sobral, P., Widdows, J., 2000. Effects of increasing current velocity, turbidity and particle-size selection on the feeding activity and scope for growth of Ruditapes decussatus from Ria Formosa, southern Portugal. J. Exp. Mar. Biol. Ecol. 245, 111-125.

Walne, P.R., 1972. The influence of current speed, body size and water temperature on the filtration rate of five species of bivalves. J. Mar. Biol. Assoc. UK 52, 345-374.

Ward, J.E., Levinton, J.S., Shumway, S.E., 2003. Influence of diet on pre-ingestive particle processing in bivalves. I: Transport velocities on the ctenidium. J. Exp. Mar. Biol. Ecol. 293, 129149.

Wildish, D.J., Kristmanson, D.D., 1993. Hydrodynamic control of bivalve filter feeders: A conceptual view. In: Dame, R.F. (Ed), Bivalve filter feeders in estuarine and coastal ecosystem processes, NATO ASI Series G: Ecological Sciences. Springer, Berlin, pp. 299-324.

Wildish, D.J., Kristmanson, D.D., 1997. Benthic suspension feeders and flow, Cambridge University Press, United Kingdom.

Wildish, D.J., Miyares, M.P., 1990. Filtration rates of blue mussels as a function of flow velocity: preliminary experiments. J. Exp. Mar. Biol. Ecol. 142, 213-219.

Wildish, D.J., Peer, D., 1983. Tidal current speed and production of benthic macrofauna in the lower bay of Fundy. Can. J. Fish. Aquat. Sci. 40, 309-321.

Ziegelmeier, E., 1969. Neue untersuchungen über die wohnrohnen-Bauweise von Lanice conchilega (Polychaeta, Sedentaria). Helgol. Meeresunters 19, 216-229. 
Table I: Parameters of the different experiments conducted with Lanice conchilega for clearance rates measurements.

\begin{tabular}{lccc} 
& Exp. 1 & Exp. 2 & Exp.3 \\
\cline { 2 - 4 } Sampling area & bay of Veys & \multicolumn{2}{c}{ Boulogne-sur-mer } \\
Sampling date & 10 June 2000 & 07 July 2000 \\
Date of experiment & 13 July 2000 & 18 July 2000 & 19 July 2000 \\
Number of organisms experimented & 69 & 69 & 74 \\
Individual wet weight (mg, mean \pm SD) & $148.2 \pm 64.6$ & $318.9 \pm 245.3$ & $465.1 \pm 159.1$ \\
Individual dry weight (mg, mean \pm SD) & $21.0 \pm 10.4$ & $48.7 \pm 39.9$ & $59.9 \pm 21.9$ \\
Individual Ash-free dry weight (mg, mean \pm SD) & $11.9 \pm 5.4$ & $30.9 \pm 26.4$ & $36.6 \pm 12.9$ \\
\hline
\end{tabular}


Table II: Averaged flow velocities applied for clearance and control experiments are listed ( \pm Standard Error). The number of recordings used to calculate the relationships is given, as well as correlations coefficients obtained between ln (Chla concentration) and time during all the experiments (ns: not significant; ${ }^{*} \mathrm{p}<0.05 ;{ }^{* *} \mathrm{p}<0.01$; ${ }^{* * *} \mathrm{p}<0.001$ ). Calculations from the slope (i.e. the opposite of the specific loss rate: $x$ for clearance experiments, $x$ ' for control experiment) of the linear regression of ln transformed data give the individual clearance rates (uncorrected and corrected from the control experiment, see text for details).

\begin{tabular}{|c|c|c|c|c|c|c|c|}
\hline & $\begin{array}{l}\text { Mean flow } \\
\text { velocity } \\
\left(\mathrm{cm} \cdot \mathrm{s}^{-1}\right) \pm \mathrm{SE}\end{array}$ & $\begin{array}{c}\text { Number } \\
\text { of } \\
\text { recording }\end{array}$ & $\begin{array}{c}\mathrm{r}^{2} \text { and } \\
\text { significance }\end{array}$ & $\begin{array}{c}\text { Slope } \\
\left(\mathrm{h}^{-1}\right)\end{array}$ & $\begin{array}{c}\text { Number of } \\
\text { L. } \\
\text { conchilega } \\
\end{array}$ & $\begin{array}{c}\text { Clearance rate } \\
\text { (uncorrected) } \\
\text { in } l^{-1} h^{-1} \text {.ind }\end{array}$ & $\begin{array}{c}\text { Clearance rate } \\
\text { (corrected from } \\
\text { control) in } l^{-1} \mathrm{~h}^{-1} \text {.ind }{ }^{-1}\end{array}$ \\
\hline \multirow[t]{5}{*}{ Exp.1 } & $4.13 \pm 0.30$ & 7 & $0.980, * * *$ & -0.095 & 69 & 0.138 & 0.116 \\
\hline & $8.56 \pm 0.55$ & 8 & $0.969, * * *$ & -0.144 & 69 & 0.208 & 0.187 \\
\hline & $14.31 \pm 0.78$ & 7 & $0.990, * * *$ & -0.153 & 69 & 0.222 & 0.221 \\
\hline & $21.94 \pm 1.74$ & 7 & $0.992, * * *$ & -0.078 & 69 & 0.112 & 0.147 \\
\hline & $27.52 \pm 1.84$ & 7 & $0.775, * *$ & 0.028 & 69 & -0.041 & 0.030 \\
\hline \multirow[t]{5}{*}{ Exp. 2} & $4.42 \pm 0.26$ & 8 & $0.963, * * *$ & -0.106 & 69 & 0.153 & 0.131 \\
\hline & $9.06 \pm .030$ & 7 & $0.984, * * *$ & -0.095 & 69 & 0.138 & 0.116 \\
\hline & $13.82 \pm 0.74$ & 7 & $0.997, * * *$ & -0.112 & 69 & 0.162 & 0.161 \\
\hline & $21.54 \pm 1.58$ & 7 & $0.993, * * *$ & -0.078 & 69 & 0.113 & 0.148 \\
\hline & $27.31 \pm 1.28$ & 7 & $0.454, \mathrm{~ns}$ & -0.007 & 69 & 0.010 & 0.080 \\
\hline \multirow[t]{5}{*}{ Exp. 3} & $4.12 \pm 0.21$ & 7 & $0.992, * * *$ & -0.053 & 74 & 0.071 & 0.049 \\
\hline & $9.29 \pm 0.45$ & 8 & $0.980, * * *$ & -0.128 & 74 & 0.173 & 0.151 \\
\hline & $14.32 \pm 0.87$ & 7 & $0.992, * * *$ & -0.099 & 74 & 0.133 & 0.132 \\
\hline & $21.71 \pm 0.85$ & 7 & $0.968, * * *$ & -0.080 & 74 & 0.108 & 0.143 \\
\hline & $27.19 \pm 2.01$ & 7 & 0.406 , ns & -0.007 & 74 & 0.009 & 0.079 \\
\hline \multirow[t]{5}{*}{ Control } & $4.21 \pm 0.40$ & 8 & $0.126, \mathrm{~ns}$ & -0.016 & 0 & & \\
\hline & $8.97 \pm 0.48$ & 7 & 0.655 ,* & -0.015 & 0 & & \\
\hline & $14.99 \pm 0.78$ & 7 & 0.036 , ns & 0.001 & 0 & & \\
\hline & $21.72 \pm 0.78$ & 6 & $0.972, * * *$ & 0.025 & 0 & & \\
\hline & $26.84 \pm 1.38$ & 7 & $0.933, * * *$ & 0.051 & 0 & & \\
\hline
\end{tabular}


Table III: Detailed calculations of global clearance rates for the oyster cultivated area in the Bay of Veys for Lanice conchilega and Crassostrea gigas (* based on data from Ropert and Goulletquer, 2000; ID: Inner Diameter of polychaete tubes)

\begin{tabular}{|c|c|c|c|c|c|c|}
\hline & & & $\begin{array}{l}\text { Average } \\
\text { Abundances } \\
\text { (ind. } \mathrm{m}^{-2} \text { ) }\end{array}$ & $\begin{array}{l}\text { Individual } \\
\text { clearance rate } \\
\left(1 . h^{-1} . \text { ind }^{-1}\right)\end{array}$ & $\begin{array}{c}\text { Clearance } \\
\text { rate } \\
\left(1 . h^{-1} \cdot \mathrm{m}^{-2}\right)\end{array}$ & $\begin{array}{c}\text { Global } \\
\text { clearance rate } \\
\left(\mathrm{l}^{-1} \mathrm{~h}^{-1} \cdot \mathrm{m}^{-2}\right)\end{array}$ \\
\hline \multirow[t]{4}{*}{$\begin{array}{c}\text { Lanice } \\
\text { conchilega }\end{array}$} & Low & $\begin{array}{c}\text { Juveniles } \\
\text { (ID }<2.8 \mathrm{~mm} \text { ), Exp } 1\end{array}$ & 700 & 0.0295 & 20.7 & \multirow{2}{*}{158.2} \\
\hline & $\left(4 \mathrm{~cm} \cdot \mathrm{s}^{-1}\right)$ & $\begin{array}{c}\text { Adults } \\
\text { (ID }>2.8 \mathrm{~mm} \text { ), Exp.3 }\end{array}$ & 2800 & 0.0491 & 137.5 & \\
\hline & \multirow{2}{*}{$\begin{array}{l}\text { Moderate } \\
\text { flow velocity } \\
\left(15 \mathrm{~cm} \cdot \mathrm{s}^{-1}\right)\end{array}$} & $\begin{array}{c}\text { Juveniles } \\
\text { (ID }<2.8 \mathrm{~mm} \text { ), Exp } 1\end{array}$ & 700 & 0.2211 & 154.8 & \multirow{2}{*}{577.9} \\
\hline & & $\begin{array}{l}\text { Adults } \\
\text { (ID>2.8 mm), Exp.3 }\end{array}$ & 2800 & 0.1511 & 423.1 & \\
\hline$\frac{\text { Crassostrea }}{\text { gigas } *}$ & $\begin{array}{l}\text { Moderate flow } \\
\text { velocity }\end{array}$ & Cultivated oysters & 225 & 3.01 & & .13 \\
\hline
\end{tabular}




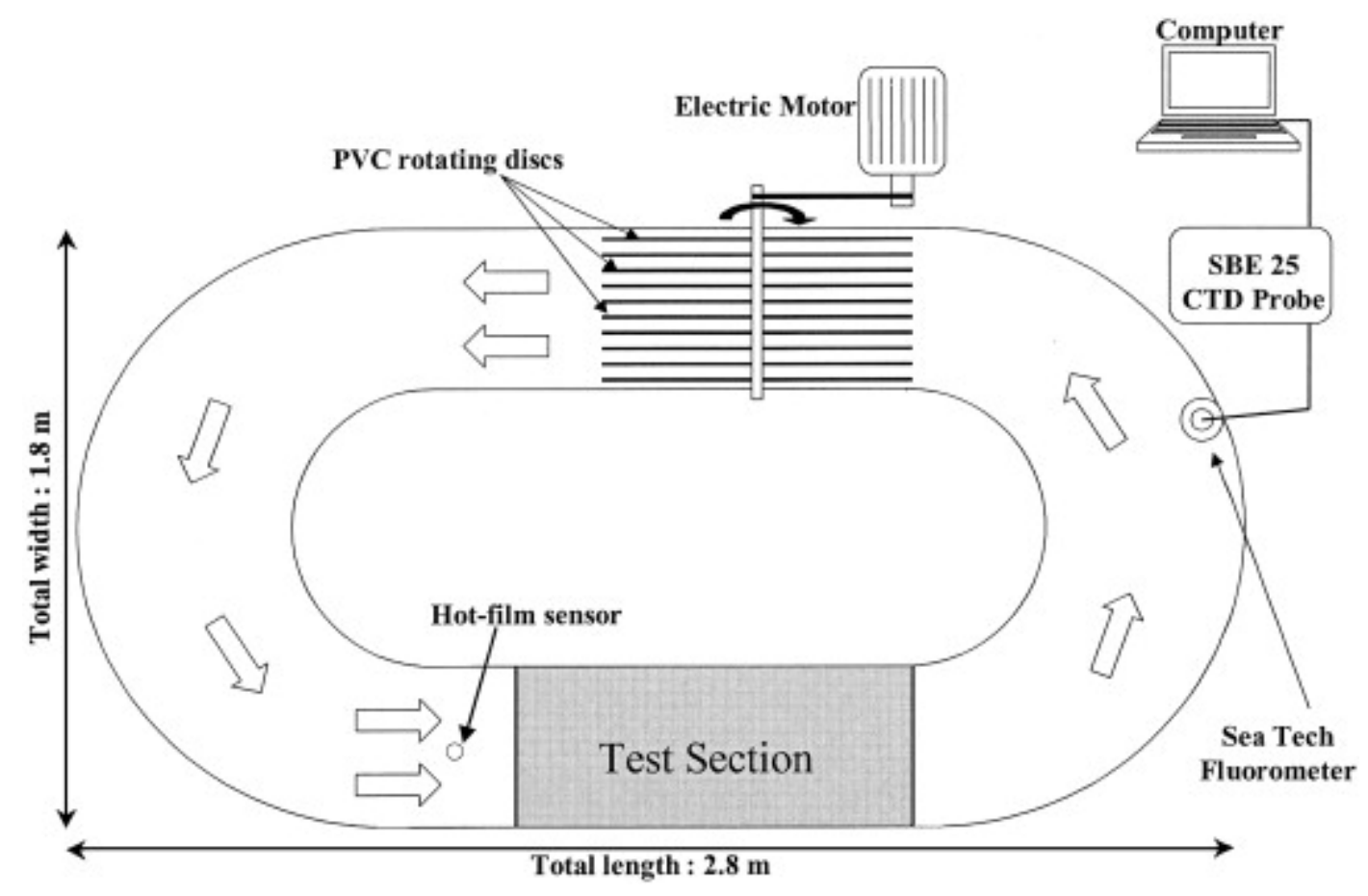

Figure 1: Design of the racetrack flume and experimental setting. Black arrow shows the rotation of PVC discs coupled to the electric motor, open arrows indicate flow direction in the flume. 

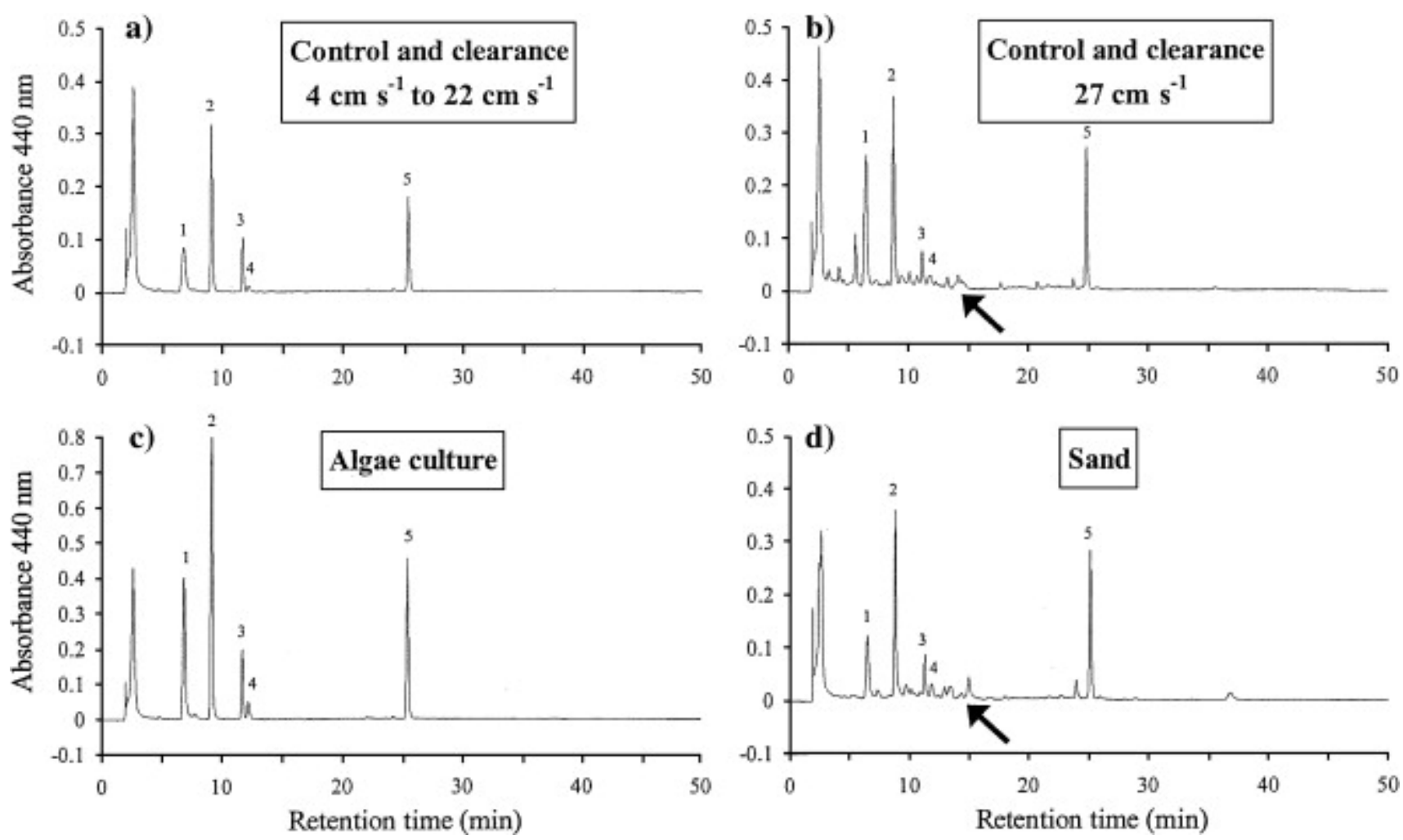

Figure 2: Typical HPLC chromatograms showing pigment patterns associated with control and clearance experiments (Exp. 3) with varying current velocities. Pigments associated with algae culture as well as sand sampled in the flume at the end of the experiment are also shown. Bold arrows evidence additional noise indicating resuspension phenomenon (see text). Peak identification: 1- Chlorophyll $c_{1}+c_{2}$, 2- Fucoxanthin, 3- Diadinoxanthin, 4- Cis-Fucoxanthin , 5Chlorophyll a 

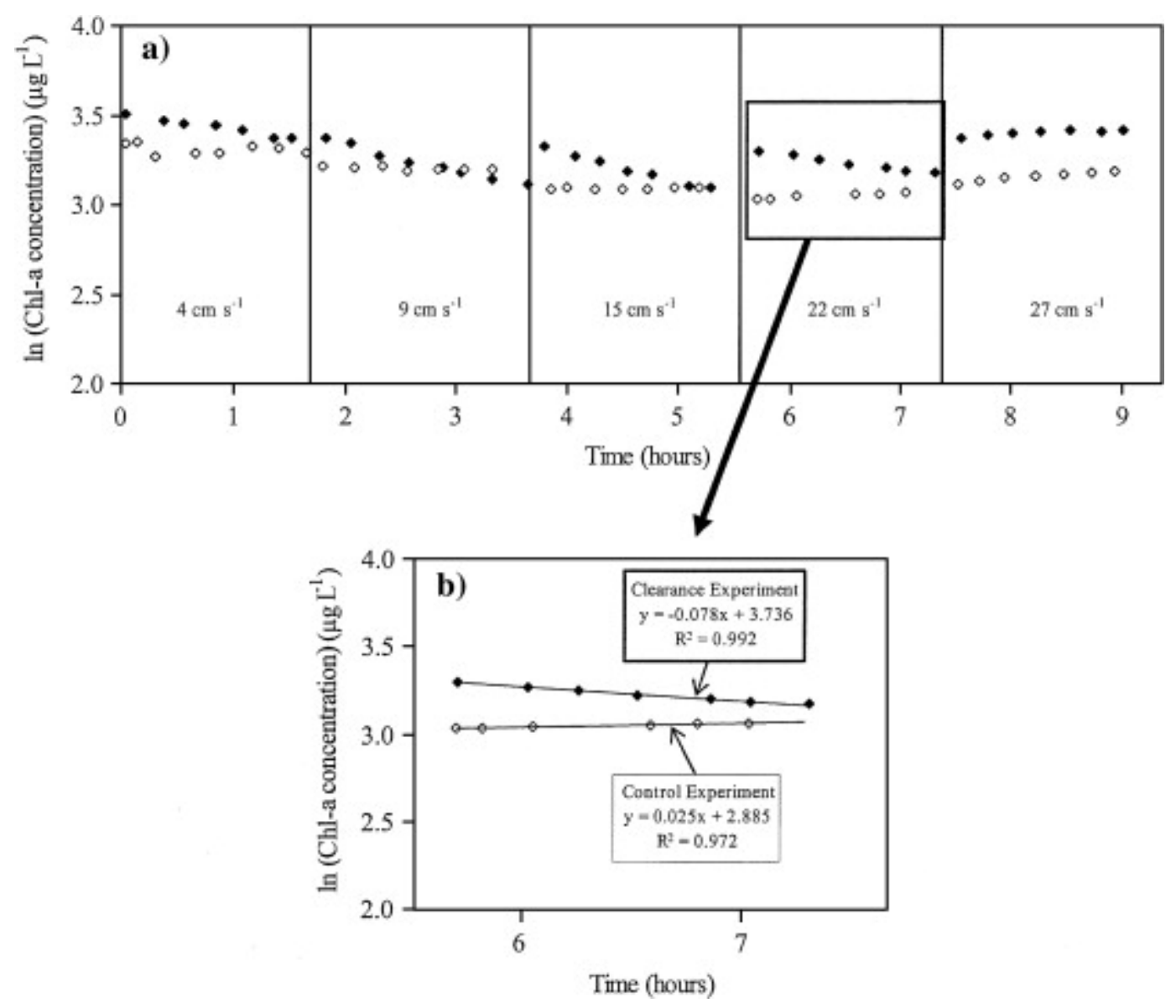

Figure 3: a) Variation with time of $\ln \left(\underline{\mathrm{Chl} \text { a }}\right.$ concentrations $\left(\mu \mathrm{g} . \mathrm{l}^{-1}\right)$ ) estimated from in vivo fluorescence during the clearance (Exp 1 with Lanice conchilega, $\bullet$ ) and the control (without $\underline{L}$. conchilega, $\diamond$ ) experiments. Flow velocity was increased from 4 to $27 \mathrm{~cm} . \mathrm{s}^{-1}$ every $1 \mathrm{~h} 45$ minutes. The sharp concentration changes observed during clearance experiment are consecutive to algal concentration readjustment performed for each velocity increase (see text). b) Detailed view of the changes recorded at $22 \mathrm{~cm} . \mathrm{s}^{-1}$, with linear fit and corresponding slopes (also see Table II) 


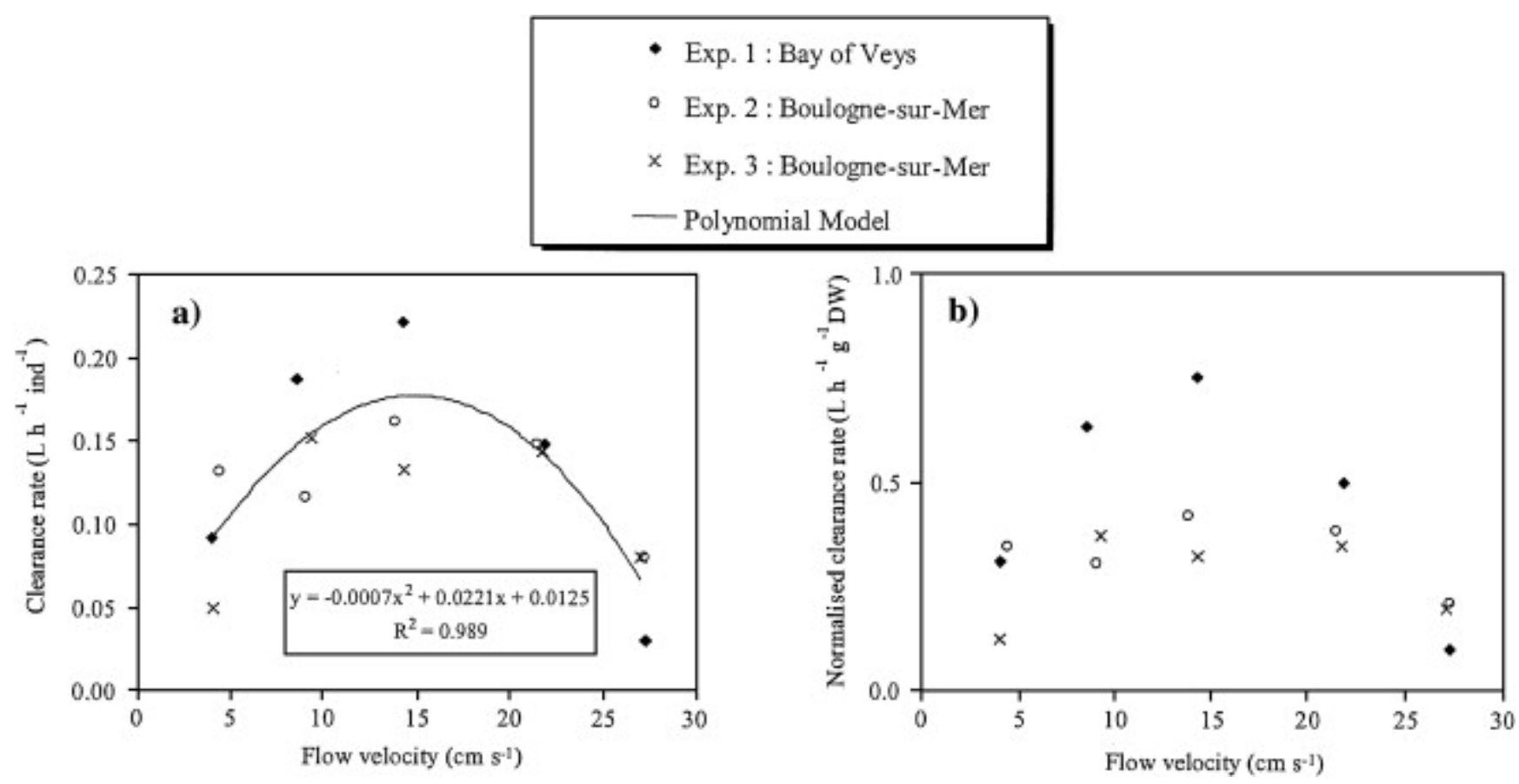

Figure 4: Clearance rates of Lanice conchilega versus flow velocity for all experiments, as expressed per individual (a) and normalized per gram of dry weight (b) 